\title{
Analysis and Design of Information Systems for Control of Raw Materials in UD. YRS Alumunium Work Using EOQ Method
}

\author{
Assaji ${ }^{1}$, Rudy Arijanto ${ }^{2}$, \\ ${ }^{1}$ Buddhi Dharma University, Information System, Banten, Indonesia \\ ${ }^{2}$ Buddhi Dharma University, Informatics Engineering, Banten, Indonesia
}

\begin{tabular}{l}
\hline SUBMISSION TRACK \\
\hline Received : Aug 21, 2020 \\
Final Revision : Sept 22, 2020 \\
Available Online : Sept 29, 2020 \\
KEYWORD \\
\hline Metode EOQ (Economic Order Quantity), ROP \\
CORRESPONDENCE \\
\hline E-mail: \\
aassaajij@ @gmail.com, \\
rudyarijanto@buddhidharma.ac.id
\end{tabular}

\section{INTRODUCTION}

In the current era of globalization, information technology and information systems are developing very fast. Information is a major need for small companies or entrepreneurs. Information that

A B S T R A C T
In the current era of globalization, information
technology and information systems are
developing very fast. YRS Alumunium Work is a
furniture company that manufactures cupboards,
stove racks, sinks, and especially for storage of
household items. The problems currently being
faced by businesses, among others; (a) recording
still using stationery and books or still using
manual recording methods, (b) ineffective stock
checking, (c) sudden out of stock, to solve the
problem it is proposed to make a system using the
web that can be integrated into stock by a
calculation method. With UML scenario
depiction (activity diagrams, usecase diagrams,
class diagrams, sequence diagrams). To check the
inventory of goods easily done effectively, know
the minimum amount of stock, and must place an
order again using the EOQ (Economic Order
Quantity) method. By using the EOQ method, it
takes into account that for bolts to get an
economical amount of inventory as much as
522.01 with a safety stock of 21 will place an
order again when the stock becomes 50 and the
total inventory cost is Rp. $110.458,4418$.

is done in writing is still inaccurate to meet the company's need for accurate, fast, and easy-to-control information for users. Understanding information systems are organized ways to collect, enter, and process and store data, and organized ways to store, manage, control, and report information in 
such a way that an organization can achieve the objectives set according to [1].

Along with technological advances and increased human activity in the trade sector, it will certainly lead to intense competition in the business world. The existence of this competition encourages each company to manage its resources optimally to produce a product that is always available when needed. One element that requires proper planning and control is inventory. Inventory is the company's most active working capital and has material value.

In trade, product inventory is an important element that needs special attention in terms of its planning and management because without product inventory, trading activities cannot be carried out. Raw materials can be obtained by buying local products or purchasing imported products. When a company buys a product, the company not only incurs costs for the product but also other costs associated with procuring a product, such as purchase transportation costs and warehousing costs. Therefore, the function of controlling and planning inventory has an important role and must be owned by every company.

YRS Alumunium Work is a furniture company that manufactures cupboards, stove racks, sinks, and especially for storage of household items. YRS Alumunium Work was founded in 2016, located at Kp. Cibeleng RT 002/005, Ds. Cijantra, Pagedangan District, Tangerang Regency. This business entity was founded by Mr. Lim Yan Lie.

The problems currently being faced by businesses, among others; (a) recording still using stationery and books or still using manual recording methods, (b) ineffective stock checking, (c) like sudden out of stock. Inventory management is management that controls every product or item that is traded in the daily operations of a company. The system required by this business, especially regarding product stock inventory with computer applications, the authors hope that after this system is implemented it can produce accurate data in an effective and efficient time.

Based on the problems that exist in the product stock inventory section of YRS Aluminum Work, it is proposed to build an Inventory controlling system at YRS Aluminum Work with the title "Analysis and design of an information system for controlling raw material supplies at UD YRS Aluminum Work with the EOQ method (case study: YRS Alumunium Work)". The information system designed for owners can easily check using a local application so that there is no shortage of stock or excess stock of goods.

\section{LITERATURES REVIEW PHP}

According to [7] PHP is a scripting language designed for building web applications.

According to [8] "PHP (or formally PHP: Hypertext Preprocessor) is a server-side script that is added to HTML". PHP itself stands for Personal Home Page Tools. This script will allow an application to be integrated into HTML so that a web page is no longer static, but dynamic.

\section{Database}

According to [9] a database is defined as a headquarters or warehouse, a place to nest or gather. The main principle of the database is data management with the main objective of flexibility and speed in the retrieval of data. The objectives of the database include efficiency, which includes speed, space \& accuracy, handling large amounts of data, sharing usage, and eliminating duplication.

\section{METHOD}

According to [2] EOQ (Economical Order Quantity) is one of the oldest and widely known inventory control techniques, this 
inventory control method answers 2 (two) important questions, namely:

1. When to order, and

2. How many should order?

The notion of EOQ is the most economical volume or amount at each purchase, according to [3].

According to [2] it is said that EOQ can be found with the following formula:

$\mathrm{EOQ}=\sqrt{\frac{2 D S}{H}}$

Notes :

EOQ = Economical quantity of inventory

$\mathrm{D}=$ Purchase of raw materials during a certain period

$\mathrm{S} \quad=$ Order fee

$\mathrm{H} \quad=$ storage cost per unit per year

So that the depiction of the graph using the EOQ method is as follows:

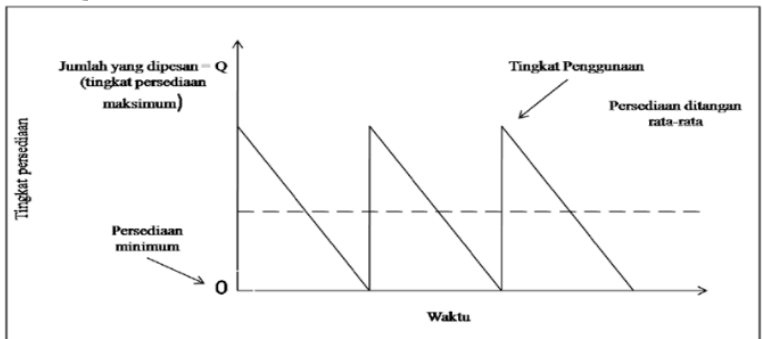

Figure 1 Graph of the inventory level of the EOQ method

Safety stock is the minimum supply (clean inventory) in the company. This net inventory is an inventory that is intended as a precaution if the company is short of goods or delays in materials ordered according to [4].

To find out the maximum amount of inventory for storage, you can use:

Safety Stock $=($ Qmax-Qr $)$

Information :

Qmax = Maximum usage

Qr = Average usage

\section{Reorder Of Point}

To calculate the point of purchase back (Reorder Of Point) raw material inventory with the following formula:
ROP$$
=\text { Qr }+ \text { Safety Stock }
$$

ROP = Reorder Point

Qr $=$ Average Usage

Safety Stock $=$ Safety Stock.

\section{Maximum Inventory and Total Inventory}

\section{Cost}

To calculate the maximum inventory (Maximum Inventory) of raw materials with the following formula:

Maximum Inventory $=$ Safety Stock + Economic Order Quantity (EOQ)

To calculate the total inventory cost (Total Inventory Cost) of raw materials with the following formula:

$\mathrm{TIC}=\frac{(H)(Q)}{2}+\frac{(S)(D)}{Q}$

Information :

TIC = Total inventory cost

$\mathrm{Q}=$ economical amount of inventory

$\mathrm{H} \quad=$ storage cost per unit per year

$\mathrm{S} \quad=$ Order fee

$\mathrm{D} \quad=$ Purchase of raw materials during a certain period so that the depiction of the graph using the EOQ method is as follows:

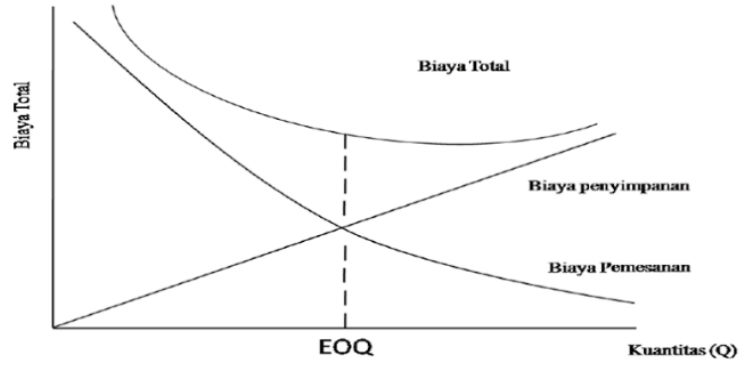

Figure 2 Cost Graph of the EOQ method

\section{RESULT}

Data must be processed beforehand with the EOQ method.

Table 1 Before Calculating the EOQ (Economic Order Quantity) Method

\begin{tabular}{|l|r|r|r|r|r|}
\hline Product & $\begin{array}{l}\text { Average } \\
\text { product } \\
\text { used/day }\end{array}$ & $\begin{array}{l}\text { Purchase } \\
\text { of Raw } \\
\text { Materials } \\
\text { (D) }\end{array}$ & $\begin{array}{l}\text { Product } \\
\text { Stock/Year }\end{array}$ & $\begin{array}{l}\text { Order Fee } \\
\text { (S) }\end{array}$ & $\begin{array}{l}\text { Storage } \\
\text { Cost (H) }\end{array}$ \\
\hline Glass & 4 & 20 & 220 & 3.300 .000 & 400 \\
\hline Hinge & 16 & 100 & 890 & 2.900 .000 & 400 \\
\hline Bolt & 29 & 500 & 1000 & 109.000 & 400 \\
\hline Handle & 19 & 100 & 900 & 410.000 & 400 \\
\hline
\end{tabular}

Notes : 

Data that has been calculated by the EOQ method.

Table 2 After Calculating the EOQ (Economic Order Quantity) Method

\begin{tabular}{|l|r|r|r|r|}
\hline Product & \multicolumn{1}{|c|}{ EOQ } & $\begin{array}{l}\text { Safety } \\
\text { Stock (SS) }\end{array}$ & $\begin{array}{l}\text { Reorder point } \\
\text { (ROP) }\end{array}$ & $\begin{array}{l}\text { Maximum } \\
\text { Inventory/Total } \\
\text { Inventory Cost } \\
\text { (TIC) }\end{array}$ \\
\hline Glass & 575 & 6 & 10 & $229.782,505$ \\
\hline Hinge & 1.204 & 9 & 25 & $481.663,783$ \\
\hline Handel & 453 & 6 & 25 & $181.107,702$ \\
\hline Hinge & 522 & 21 & 50 & $110.458,4418$ \\
\hline
\end{tabular}

Bolt:

$$
\begin{aligned}
\text { EOQ } & =\sqrt{\frac{2 D S}{H}} \\
& =\sqrt{\frac{2 \times 500 \times 109.000}{400}} \\
& =\sqrt{\frac{109.000 .000}{400}} \\
& =\sqrt{272500} \\
& =522,01532
\end{aligned}
$$

$$
\begin{aligned}
\text { Safety Stock } & =(\text { Qmax-Qr }) \\
& =(50-29) \\
& =21
\end{aligned}
$$

$$
\begin{aligned}
\text { ROP } & =\text { Qr }+ \text { Safety Stok } \\
& =29+21 \\
& =50 \\
\text { TIC } & =\frac{(H)(Q)}{2}+\frac{(S)(D)}{Q} \\
& =\frac{(400)(522,01532)}{2}+\frac{(109.000)(29)}{522,01532} \\
& =104403,064+6055,3778 \\
& =110458,4418
\end{aligned}
$$

Based on the questionnaires that have been filled in by the respondents, here are the percentages:

Table 3 Percentage of Questionnaires

\begin{tabular}{|l|c|c|}
\hline \multirow{2}{*}{} & \multicolumn{2}{|c|}{$\begin{array}{c}\text { Percentage of } \\
\text { Respondents }\end{array}$} \\
\cline { 2 - 3 } & Yes & No \\
\hline Can you operate a computer? & $100 \%$ & $0 \%$ \\
\hline Is the system display attractive? & $100 \%$ & $0 \%$ \\
\hline $\begin{array}{l}\text { Do the buttons on the system match their } \\
\text { function? }\end{array}$ & $100 \%$ & $0 \%$ \\
\hline Does every button on the system work? & $100 \%$ & $0 \%$ \\
\hline Is system operation easy to understand? & $20 \%$ & $80 \%$ \\
\hline $\begin{array}{l}\text { Do you have an internet network at your } \\
\text { place of work? }\end{array}$ & $20 \%$ & $80 \%$ \\
\hline $\begin{array}{l}\text { Does the system that has been made make } \\
\text { work easier? }\end{array}$ & $80 \%$ & $20 \%$ \\
\hline $\begin{array}{l}\text { Does the system that has been created } \\
\text { increase the effectiveness of the work? }\end{array}$ & $80 \%$ & $20 \%$ \\
\hline Is the system a complete enough report? & $100 \%$ & $0 \%$ \\
\hline $\begin{array}{l}\text { Is it a system that has controlled inventory } \\
\text { reports? }\end{array}$ & $100 \%$ & $0 \%$ \\
\hline
\end{tabular}

\section{DISCUSSION}

According to [5] UML is "a system development technique that uses a graphical language as a tool for documentation and specification on the system".

\section{Activity diagram}

describes the workflow or activity of a system or business process [6].

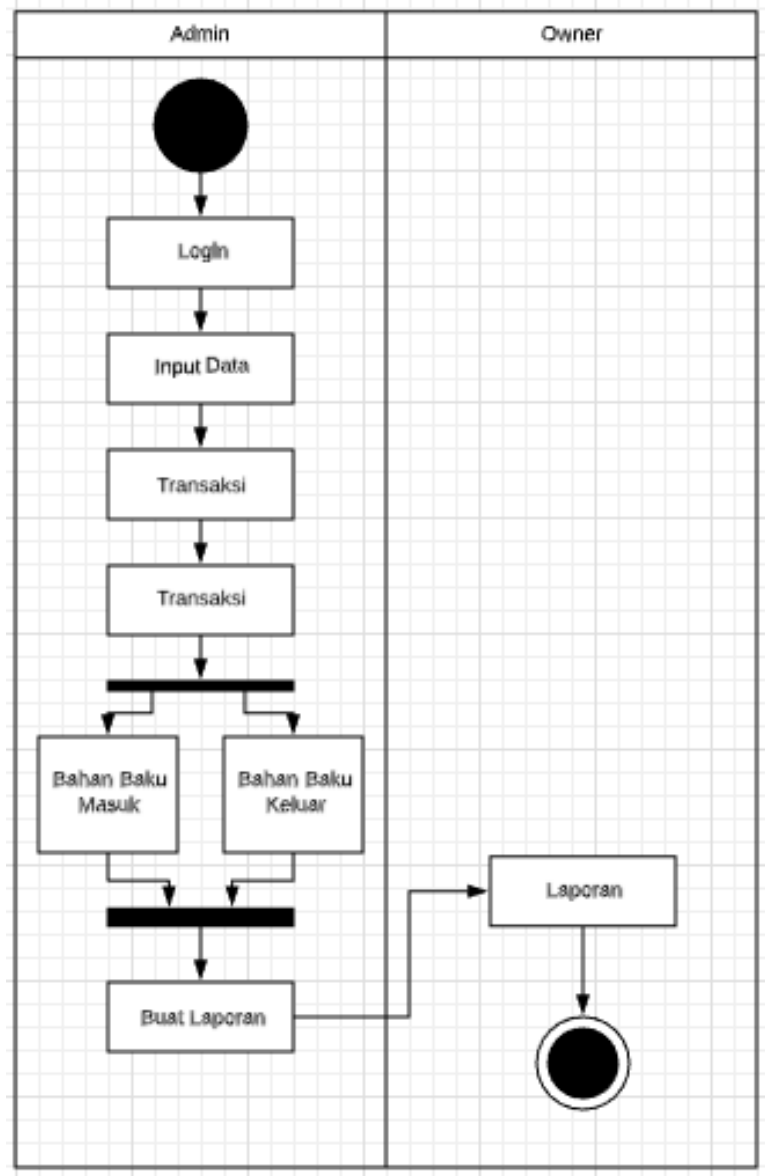

Figure 3 Activity diagram

\section{Usecase}

According to [6] Usecase or usecase diagram is modeling of information system behavior to be made. 


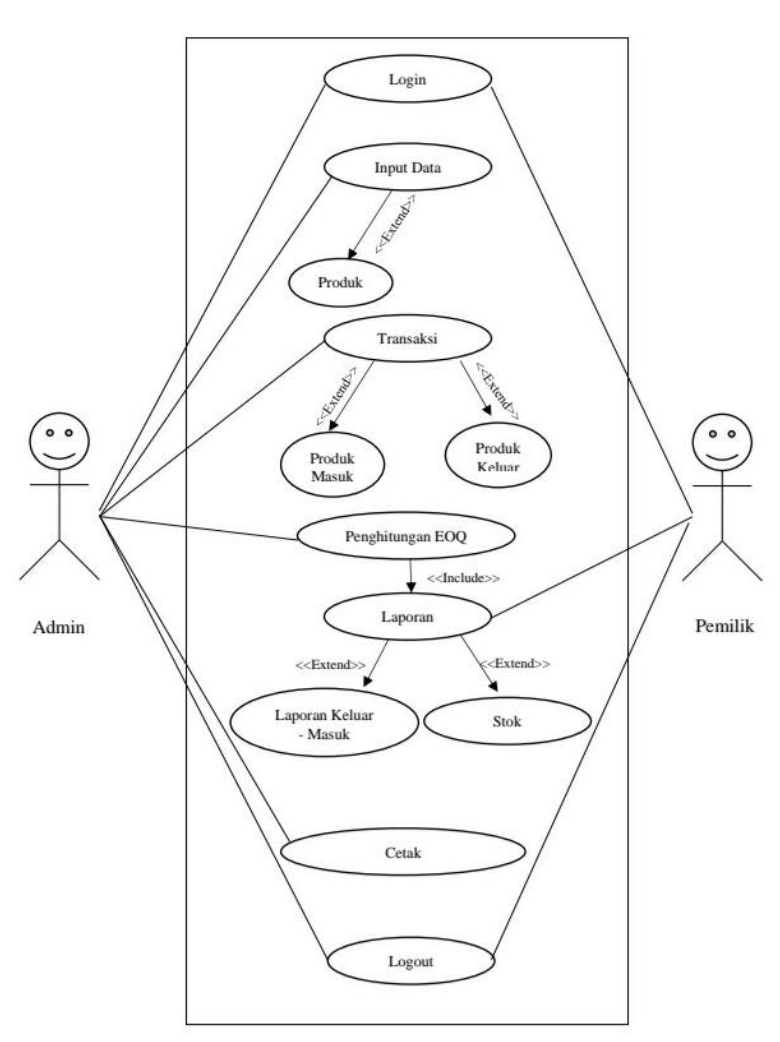

Figure 4 Usecase

\section{Class Diagram}

Relations between tables on the proposed system at UD. YRS Alumunium Work, as follows:

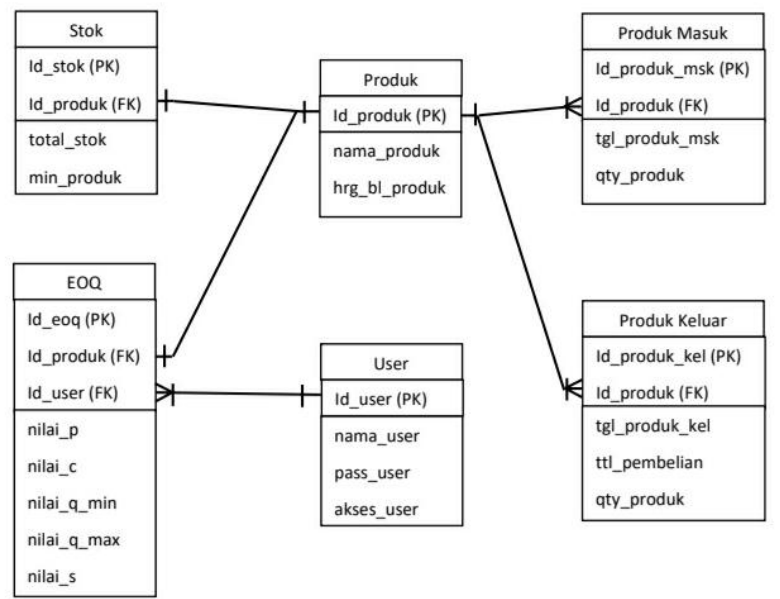

Figure 9 Class Diagram

\section{User Interface}

Display Login on the UD system. YRS Aluminum Work.

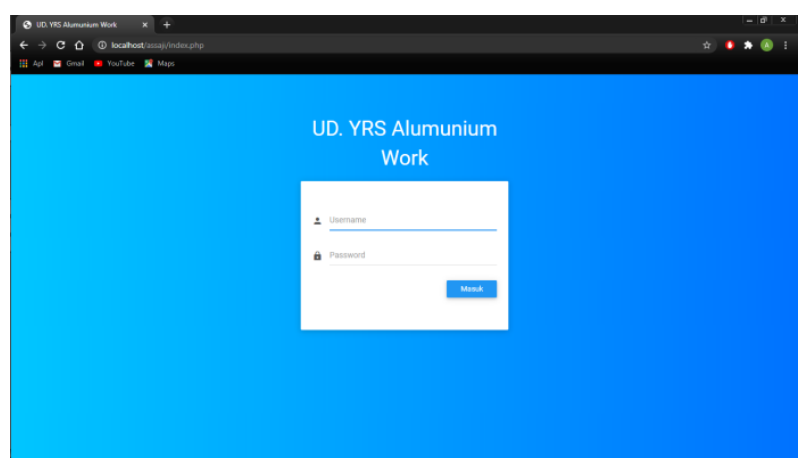

Figure 10 Login

A home display system that displays a brief history of UD. YRS Aluminum Work.

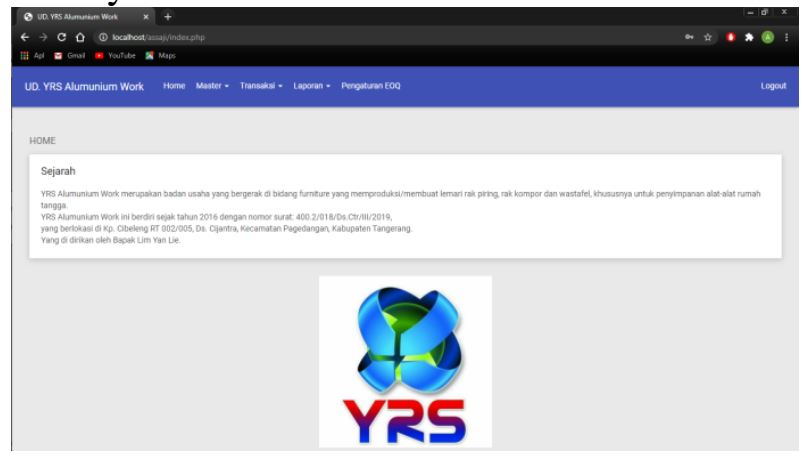

Figure 11 Home

Product Master display that displays what items are in the UD system. YRS Aluminum Work.

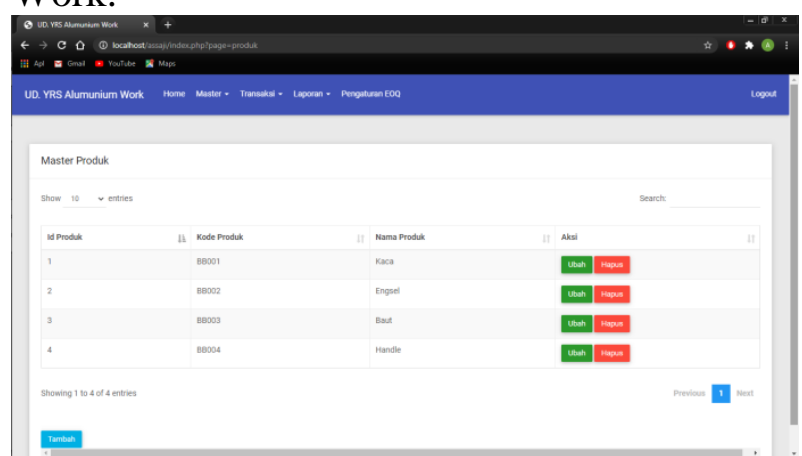

Figure 12 Product Master

Display Product Transactions that can make product entry and exit transactions.

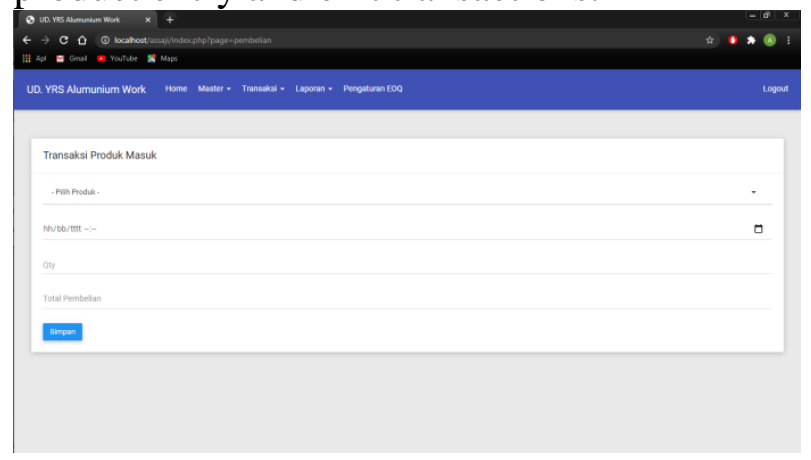

Figure 13 Product Transactions 
Report view that displays reports of in and out, stock, and can view detailed transaction history.

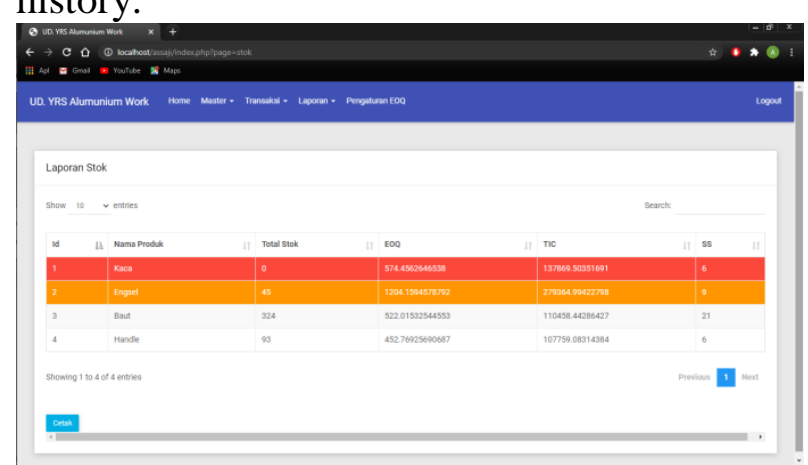

Figure 14 Report

\section{CONCLUSION}

By using the EOQ method, it takes into account that for bolts to get an economical amount of inventory of 522.01 pcs with a safety stock of 21 , will place an order again when the stock becomes 50 and the total inventory cost is Rp. $110.458,4418$.

\section{REFERENCES}

[1] Krismaji, Sistem Informasi Akuntansi, Yogyakarta: Unit Penerbit, 2015.

[2] J. Heizer dan B. Render, Manajemen Operasi: Manajemen Keberlangsungan dan Rantai Pasokan, Jakarta: SalembaEmpat, 2015.

[3] I. Gitosudarmo, Manajemen Pemasaran, Yogyakarta: BPFE, 2014.

[4] D. Wahyudi, "Analisis Empiris Pengaruh Aktivitas Corporate Social Responsibility (CSR) terhadap Penghindaran Pajak di Indonesia," Jurnal Lingkar Widyaiswara. Edisi 2 No. 4., 2015.

[5] S. Mulyani, Metode Analisis Dan Perancangan Sistem, Bandung: Abdi Sistematika, 2016.

[6] A. Rosa dan M. Shalahuddin, Rekayasa Perangkat Lunak Terstruktur dan Berorientasi Objek, Bandung: Informatika Bandung, 2015.

[7] B. Raharjo, Belajar Otodidak Membuat Database Menggunakan MySQL, Bandung: Informatika, 2011.

[8] Y. Kustiyahningsih, Pemrograman Basis Data Berbasis Web Menggunakan PHP \& MySQL, Jakarta: Graha Ilmu, 2011.

[9] Yakub, Pengantar Sistem Informasi, Yogyakarta: Graha Ilmu, 2012.

\section{BIOGRAPHY}

Assaji, Graduated in the Information Systems Study Program (S1) in the field of Electronic Business, 2020.

Rudy Arijanto, Graduated from the Information Systems Study Program (S1) in 1997. Informatics Engineering Study Program (S2) in 2008. Currently, he is a lecturer at the Informatics Engineering Study Program, Buddhi Dharma University. 